Joanna Parysek, Błażej Karolewicz*

\title{
Wpływ czynników kulturowych na uksztaltowanie systemów rachunkowości na świecie na przykładzie rachunkowości chińskiej
}

\section{Wprowadzenie}

Krajowe systemy rachunkowości zróżnicowane są pod wieloma względami. Zbiór tych czynników określany jest jako opis przestrzeni oraz środowiska, w którym jest realizowany aparat rachunkowości. Zdawałoby się, że im bardziej zróżnicowana społeczność w kraju, tym większe są oczekiwania od ogólnych mechanizmów działających na rynku, gdyż muszą one zaspokoić różnorakie potrzeby. Warto zwrócić uwagę na fakt, iż opis ten $\mathrm{w}$ wielorakim stopniu determinowany jest także wieloma pobudkami pozakulturowymi, tworzonymi m.in. przez środowisko historyczne, społeczne, prawne, gospodarcze, oddziałujące zarówno na rachunkowość, jak i na sposób, w jaki wypełnia ona powierzone jej zadania.

Na przykładzie wielowymiarowej kultury Kraju Środka w niniejszym rozdziale zostanie przybliżona problematyka historii i rozwoju rachunkowości w Chinach. Rozwój rachunkowości chińskiej, jak również jej obecna postać są wypadkową oddziaływania wielu elementów, wśród których czynnikom kulturowym przypisuje się wielkie znaczenie w budowaniu jej historycznego i teraźniejszego kształtu.

\section{Wpływ kultury na kształtowanie się systemów rachunkowości}

„Kultura definiowana jest zwykle przez pryzmat podzielanych wartości, postaw, wierzeń, rytuałów i zachowań określonych grup ludzi”" ${ }^{\text {. Na }}$

\footnotetext{
* Studenci ze Studenckiego Koła Naukowego Rachunkowości KONTO, Uniwersytet Ekonomiczny w Poznaniu, Wydział Zarządzania, Katedra Rachunkowości, al. Niepodległości 10, 61-875 Poznań.
} 
kulturę składa się wiele elementów, między innymi: wiara, prawo czy zwyczaje. Nie jest to twór zapisany w genach człowieka, lecz jest jego zachowaniem, którego uczymy się od społeczeństwa, poprzez przyswajanie wartości, rytuałów, symboli ${ }^{2}$.

Jest to zjawisko społeczne, jednakowe dla określonego środowiska społecznego. „Kultura obejmuje nie tylko działania wysublimowane, lecz także całą sferę zwykłych, codziennych zachowań, takich jak sposób pozdrawiania się, okazywanie lub skrywanie uczuć, jedzenie, zachowywanie fizycznej odległości w kontaktach międzyludzkich”3. Wpływa więc ona na każdy obszar, każdą dziedzinę życia.

Przyjmując takie założenie, nie można nie zauważyć, iż kultura jest jednym z czynników kształtujących systemy rachunkowości na świecie.

Rachunkowość to złożony system, na który wpływ wywierają różnego rodzaju czynniki. Zaliczyć do nich można te o charakterze zewnętrznym, jak szlaki handlowe, kierunki handlu zagranicznego, oraz wewnętrzne, czyli polityka danego kraju, prawo, system podatkowy, edukacja. Z licznych definicji pojęcia „rachunkowość” wynika, iż jest to system ewidencji mający na celu pomiar wyników działalności jednostki, jej stanu majątkowe i finansowego, w celu kontroli i ułatwienia podejmowania decyzji ${ }^{4}$. Jednakże cel ten i potrzeba informacji mogą być rozpatrywane w różny sposób w zależności od uwarunkowań kulturowych danego społeczeństwa. Różnice kulturowe mogą być zatem podstawą do wyjaśniania a nawet przewidywania odmienności systemów rachunkowości w środowisku międzynarodowym i mieć znaczący wpływ na harmonizację i upowszechnianie integracji ekonomicznej ${ }^{5}$.

Czynnikami często pomijanymi w analizie zachowań ekonomicznych są religia i tradycja. Barro and McCleary (2003) oszacowali wpływ przynależności do grupy religijnej na wyniki ekonomiczne, poprzez przeprowa-

\footnotetext{
${ }^{1}$ J. Adamek, Kulturowe uwarunkowania rachunkowość w świetle założeń i praktyki rachunkowości islamskiej i chińskiej, CeDeWu, Warszawa 2012, s. 19.

${ }^{2}$ Ibidem, s. 19-20.

${ }^{3}$ G. Hofstede, M. Minkov, Kultury i organizacje, Polskie Wydawnictwo Ekonomiczne, Warszawa 2011, s. 21.

${ }^{4}$ M. Cieślak, Podejście etyczne $w$ rachunkowości a jakość sprawozdania finansowego, Wydawnictwo Uniwersytetu Ekonomicznego w Poznaniu, Poznań 2011, s. 18.

${ }^{5}$ S.J. Gray, Towards a Theory of Cultural Influence on the Development of Accounting Systems Internationally, Abacus 1988, s. 1-13.
} 
dzenie międzynarodowej ankiety odnośnie do religijności. W swoich badaniach dowiedli, że wzrost w uczęszczaniu wiernych do kościoła na ogół powoduje spadek wzrostu ekonomicznego, podczas gdy wzmocnienie się wiary $\mathrm{w}$ piekło i życie pośmiertne powoduje przeciwną sytuację, czyli przyrost wzrostu ekonomicznego ${ }^{6}$.

\section{Charakterystyka kultura chińskiej - wierzenia, filozofia}

System rachunkowości w Chinach został ukształtowany głównie przez czynniki kulturowe. Kultura chińska dzieli się na dwie części, a mianowicie tradycyjną (związaną z konfucjanizmem, koncepcją Yin i Yang, Feng Shui oraz buddyzmem), a także nowoczesną (odnoszącą się do Teorii Państwa, Teorii Klas, Marksizmu oraz rewolucji Kulturowej). W kolejnej części artykułu każda ze wspomnianych kultur zostanie przedstawiona w postaci opisu głównych cech i założeń.

„Konfucjanizm jest systemem filozoficzno-religijnym, wspierającym się na założeniu, że budowa idealnego społeczeństwa oraz osiągnięcie pokoju na świecie staje się możliwe tylko pod warunkiem podporządkowania się obowiązkom wynikającym z przyjętej i uznanej hierarchii społecznej, zachowania i pielęgnowania tradycji, czystości, ładu i porządku. (...) Jako doktryna filozoficzno-religijna konfucjanizm nie uznaje bezpośrednich przeciwieństw pomiędzy takimi określeniami i stanami jak dobry - zły czy prawy - niegodny. Skupia się ona bardziej na równowadze sił i poszukiwaniu „złotego środka”, co znajduje m.in. swoje implikacje w sposobie postrzegania i rozwiązywania sporów dotyczących i reprezentowanych przez różne, często sprzeczne interesy członków grup społecznych"”.

Koncepcja Yin i Yang to filozoficzna zasada i bez wątpienia jeden z najlepiej znanych symboli we Wschodniej Azji. Zgodnie z filozofią Yin i Yang wszystkie zjawiska we wszechświecie są formowane przez połączenie dwóch przeciwnych energii kosmicznych, nazywanych Yin i Yang. Yin reprezentuje „kobiecą” energię, taką jak księżyc, noc, słabość, ciemność, kobiecość, natomiast Yang to energia „męska”, taka jak słońce, dzień, siła,

\footnotetext{
${ }^{6} \mathrm{https}: / /$ ssrn.com/abstract=1136703 [dostęp: 4.03.2016].

${ }^{7}$ J. Adamek, Mikrofinanse islamskie - założenia, produkty, praktyka, CeDeWu, Warszawa 2010, s. 89-90.
} 
jasność. Obie te energie nie mogą współistnieć i jednoczyć by utworzyć całość, czego symbolem są biała i czarna kropka, natomiast falowana linia świadczy o tym, że nie ma całkowitego rozdzielenia tych dwóch kontrastów.

Feng Shui to wywodząca się z Chin filozofia oraz technika planowania przestrzeni, która odnajduje idealne i dogodne miejsce dla mieszkańca, zarówno żywego, jak i martwego. Opiera się na wiekach obserwacji i doświadczaniu otaczającego świata, na ich podstawie starożytni Chińczycy wynaleźli niepowtarzalną drogę współoddziaływania ze środowiskiem w harmonijny sposób. Ważniejszym celem tej filozofii jest osiągnięcie harmonii i równowagi w interakcji ze środowiskiem naturalnym, ludźmi i kosmosem, co zgodnie $\mathrm{z}$ wierzeniami ma owocować szczęściem ${ }^{8}$.

Buddyzm to filozoficzno-religijny system, którego założycielem był Shakyamuni. Kładzie nacisk na ludzkie starania i usamodzielnienie człowieka. Zakłada, że każdy człowiek jest zdolny do osiągnięcia oświecenia. Pierwszy nauczyciel i jednocześnie założyciel buddyzmu twierdził, że jest jedynie zwykta ludzka istota, nauczat, że oświecenie zależy jedynie od poznania prawdy, a nie od ślepej wiary'.

\section{Modele księgowości w Chinach}

Historia powstania systemu rachunkowości w Chinach, należy do jednych z najdłuższych, gdyż jej początku można doszukiwać się 3000 lat wstecz. System ten zmieniał się na przestrzeni lat pod wpływem przemian społecznych, politycznych, ekonomicznych i kulturowych. Na podstawie poszczególnych etapów zmian można wyróżnić siedem modeli chińskiej rachunkowości.

\footnotetext{
${ }^{8}$ H. Ke-Tsung, Traditional Chinese Site Selection - Feng Shui: An Evolutionary/Ecological Perspective, Journal of Cultural Geography 2001, s. 75-76.

${ }^{9} \mathrm{M}$. Yang Hong, The influence of Buddhism on accounting in medieval China, University of Wollongong 2014, s. 13.
} 
Rysunek 1. Modele księgowości w Chinach na przestrzeni czasu

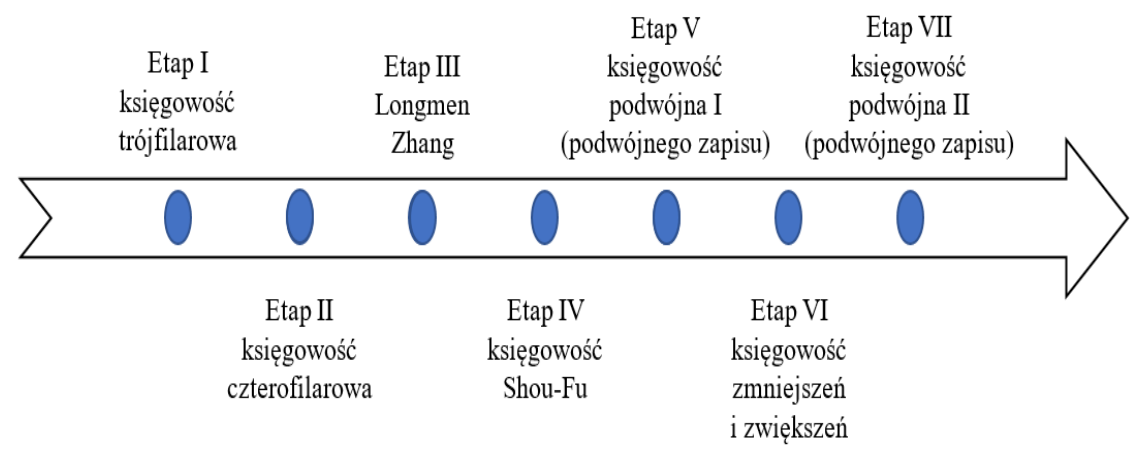

Źródło: opracowanie własne na podstawie J. Adamek, Mikrofinanse islamskie-założenia, produkty, praktyka, CeDeWu, Warszawa 2010, s. 104.

Model księgowości trójfilarowej ( $\mathrm{Ru} \mathrm{Chu})$ uznawany jest za najstarszą, a jednocześnie pierwszą metodę księgowania, która stała się zarazem bazą do tworzenia następnych modeli. Wywodzi się z czasów Zachodniej Dynastii Zhou. Jej zadaniem było umożliwienie kontroli zmian zachodzących w majątku Dynastii.

Model księgowości czterofilarowej (Shizhufa) to drugi z modeli, należący do tzw. księgowości pojedynczej. W porównaniu z poprzednią, księgowością trójfilarową, model ten został rozszerzony o rachunkowość prywatną. Było to spowodowane rozwojem handlu oraz pojawieniem się w obrocie gospodarczym papierowego pieniądza.

Księgowość Bramy Smoka (Longmen Zhang) rozwinęła się jako odpowiedź na rozwijającą się gospodarkę, tym razem kapitalistyczną. Wprowadziła ona do rachunkowości chińskiej tzw. rachunkowość podwójną, co prowadziło do dokonywania zapisów po obu stronach równania.

Księgowość Shou-Fu rozwija Księgowość Bramy Smoka o uwzględnienie zarówno transakcji gotówkowych, jak i bezgotówkowych. W tym przypadku księgowość oparta została na formule tzw. Czterech stóp (inaczej: Czterech nóg), dzięki czemu możliwe było zestawienie kont zarówno wpływów (Jin), jak i wydatków (Jiao). To z kolei pozwalało na kalkulację zysków i strat, a także prezentację tej informacji w odrębnym zestawieniu sprawozdawczym, które nosiło nazwę Cai Xian Jie Ce.

Tradycyjna księgowość podwójna (etap I) to moment zarysowania się w Chinach modelu rachunkowości europejskiej. Model ten opierał się na księgowości podwójnej, lecz także na rachunkowości charakterystycznej 
dla gospodarki i ekonomii socjalistycznej. Swoim zasięgiem nie obejmowała już tylko rolnictwa, ale zaczęto ją również stosować w przemyśle, handlu, instytucjach finansowych.

Powstanie Księgowości zwiększeń i zmniejszeń związane było z dezaprobatą i niedostosowaniem księgowości europejskiej do panujących realiów w ówczesnych Chinach. Opierała się na pięciu założeniach ${ }^{10}$ :

$\checkmark$ teorii przepływu funduszu, z która wierze się następujące równanie: fundusze wykorzystane (użyte zasoby) = fundusze posiadane (roszczenia wobec zasobów),

$\checkmark$ podziale kont na dwie grupy: funduszy posiadanych i wykorzystanych,

$\checkmark$ zapisie w dzienniku opierającym się na wykorzystaniu chińskich znaków, które wskazywały jednocześnie na rodzaj transakcji,

$\checkmark$ zasadzie zapisu: zwiększenie funduszy jest ujemne, gdy transakcja wiąże się z napływem aktywów lub zobowiązań, a zmniejszenie funduszy łączy się z księgowym ujęciem wpływu zasobów gospodarczych lub zmniejszeniem zobowiązań,

$\checkmark$ zamknięciu zgodnym z formułą: bilans początkowy + suma zwiększeń - suma zmniejszeń = bilans zamknięcia.

Tradycyjny model księgowości podwójnej (etap II) to model aktualnie stosowany w Chinach, zgodny z wymaganiami dynamicznie rozwijającej się gospodarki $^{11}$.

\section{Wpływ czynników kulturowych na rachunkowość}

Jak zostało już wcześniej wspomniane, kultura miała duży wpływ na ukształtowanie się sytemu rachunkowości w Chinach. Tabela 1 przedstawia jak poszczególne czynniki wpłynęły na rachunkowość chińską. Ponadto, wpływ poszczególnych czynników można zaobserwować chociażby w sposobie nazewnictwa procesów ewidencyjnych, na co wpływ miało Feng Shui, np. Longmen Zhang (Księgowość Bramy Smoko), czy Tian Di He Zhang (Księgowość nieba i ziemi). Również zaakcentowanie równowagi zapisów księgowych oraz brak rozróżnienia kont jest skutkiem czynnika

\footnotetext{
${ }^{10}$ J. Adamek, Kulturowe uwarunkowania rachunkowość $w$ świetle założeń i praktyki rachunkowości islamskiej i chińskiej, CeDeWu, Warszawa 2012, s. 108.

${ }^{11}$ Ibidem, s. 104-110.
} 
kulturowego, jakim jest koncepcja Yin i Yang. Natomiast konserwatywne podejście do zmian i skupienie na rachunkowości państwowej jest skutkiem systemu filozoficzno-religijnego, jakim jest konfucjanizm.

Tabela 1. Wpływ czynników kulturowych na rachunkowość chińską

\begin{tabular}{|c|c|}
\hline $\begin{array}{c}\text { Czynniki } \\
\text { kulturowe }\end{array}$ & Rachunkowość chińska \\
\hline \multicolumn{2}{|r|}{ Metodyka prowadzenia ksiąg rachunkowych } \\
\hline $\begin{array}{l}\text { Koncepcja Yin } \\
\text { i Yang } \\
\text { Feng Shui } \\
\text { Konfucjanizm }\end{array}$ & 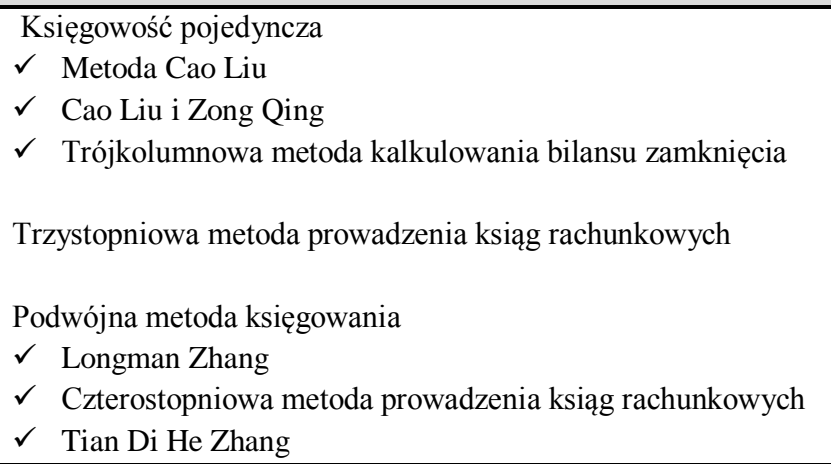 \\
\hline \multicolumn{2}{|r|}{ Informacje księgowe } \\
\hline $\begin{array}{l}\text { Feng Shui } \\
\text { Konfucjanizm }\end{array}$ & $\begin{array}{l}\text { Użytkownicy - cesarze i administracja rządowa } \\
\text { Treść - budżet rządowy i podatki } \\
\text { Zastosowanie - odbicie zasad i zwyczajów Feng Shui w procesie } \\
\text { decyzyjnym }\end{array}$ \\
\hline \multicolumn{2}{|r|}{ Regulacje rachunkowości } \\
\hline $\begin{array}{l}\text { Feng Shui } \\
\text { Konfucjanizm }\end{array}$ & $\begin{array}{l}\text { Wysoko rozwinięte rządowe regulacje rachunkowości } \\
\text { Kontrola rządowa i ustanowienie standardów } \\
\text { Brak sformalizowanych standardów dla sektora prywatnego }\end{array}$ \\
\hline \multicolumn{2}{|r|}{ Zawód księgowego } \\
\hline $\begin{array}{l}\text { Buddyzm } \\
\text { Konfucjanizm }\end{array}$ & $\begin{array}{l}\text { Status profesji księgowego } \\
\text { Arystokraci jako rządowi urzędnicy zajmujący się rachunkowo- } \\
\text { ścią } \\
\text { Księgowi w sektorze prywatnym - brak kwalifikacji }\end{array}$ \\
\hline \multicolumn{2}{|c|}{ Rachunkowość rządowa vs. rachunkowość sektora prywatnego } \\
\hline $\begin{array}{l}\text { Feng Shui } \\
\text { Konfucjanizm } \\
\text { Buddyzm }\end{array}$ & $\begin{array}{l}\text { Rachunkowość rządowa } \\
\checkmark \quad \text { ważna rola w systemie rządowym } \\
\checkmark \quad \text { wysoko rozwinięty system rachunkowości } \\
\checkmark \quad \text { funkcja }\end{array}$ \\
\hline
\end{tabular}




\begin{tabular}{|l|l|}
\hline & Rachunkowość sektora prywatnego \\
& $\checkmark$ rola społeczna \\
& $\checkmark$ bez specjalnego ukierunkowania na zysk \\
& $\checkmark$ funkcja społeczna \\
\hline
\end{tabular}

Źródto: J. Adamek, Mikrofinanse islamskie-założenia, produkty, praktyka, CeDeWu, Warszawa 2010, s. 87.

\section{Zakończenie}

Przeszły oraz aktualny obraz chińskiej rachunkowości jest wypadkową oddziaływania wielu determinant, wśród których tym o charakterze kulturowym przypisuje się bardzo duże znaczenie. Czas rozwoju systemu pomiaru i ujawnień rachunkowych w Kraju Środka był podporządkowywany wyzwaniom, jakie stawiało środowisko funkcjonowania tego agregatu, które kształtowane było m.in. przez feng shui, taoizm, buddyzm czy konfucjanizm.

Komponenty te stworzyły przestrzeń kulturową, która stała się ważnym detalem determinującym zarówno historyczny, jak również teraźniejszy kształt chińskiej rachunkowości.

\section{Bibliografia}

Adamek J., Kulturowe uwarunkowania rachunkowość w świetle zatożeń i praktyki rachunkowości islamskiej i chińskiej, CeDeWu, Warszawa 2012.

Adamek J., Mikrofinanse islamskie - zatożenia, produkty, praktyka, CeDeWu, Warszawa 2010.

Adamek J., Rachunkowość, a ideologia na przyktadzie chińskiego modelu księgowości wzrostów i spadków, Zeszyty Teoretyczne Rachunkowości, t. 66 (122), SKwP, Warszawa 2012.

Cieślak M., Podejście etyczne w rachunkowości, a jakość sprawozdania finansowego, Wydawnictwo Uniwersytetu Ekonomicznego w Poznaniu, Poznań 2011.

Gray S. J., Towards a Theory of Cultural Influence on the Development of Accounting Systems Internationally, Abacus 1988.

Hofstede G., Minkov M., Kultury i organizacje, Polskie Wydawnictwo Ekonomiczne, Warszawa 2011.

Ke-Tsung H., Traditional Chinese Site Selection - Feng Shui: An Evolutionary/Ecological Perspective, Journal of Cultural Geography 2001. 
Yang Hong M., The influence of Buddhism on accounting in medieval China, University of Wollongong 2014.

http://citeseerx.ist.psu.edu/viewdoc/download?doi=10.1.1.474.8138\&rep=rep1\&ty pe=pdf, [dostęp: 3.03.2016].

http://www.acis.pamplin.vt.edu/faculty/tegarden/5034/handouts/Gray-Abacus1988.pdf, [dostęp: 3.03.2016].

https://ssrn.com/abstract=1136703 [dostęp: 4.03.2016] 